\title{
FUMIGANT AND REPELLENT EFFECTS OF SOME NATURAL OILS AGAINST SITOPHILUS ORYZAE (L.) AND CALLOSOBRUCHUS MACULATUS (F.)
}

\author{
ABDEL-FATTAH, NILLY A. H. and DOAA, M. BORAEI
}

Plant Protection Res. Institute, ARC, Dokki, Giza, Egypt.

(Manuscript received4September 2016)

\begin{abstract}
$\mathrm{T}$ ests were performed to study the effect of toxicity and repellency of six natural oils, on rice weevil, Sitophilus oryzae and cowpea beetle, Callosobruchus maculatus. Three concentrations of natural oils were tested for the fumigation and four concentrations for repellent effects. The exposure times of fumigation were 5 days for Sitophilus oryzae and 3 days for Callosobruchus maculatus. Data of repellency test were taken at 6, 12,24 and 48 hours in all experiments. After treatment, the samples were held under constant conditions in rearing room at $30 \pm 2^{\circ} \mathrm{C}$ and $65 \pm 5 \%$ R.H. Results showed that Callosobruchus maculatus adults were more susceptible to all tested oils than Sitophilus oryzae. Increasing the oils concentration and exposure time increased the fumigant toxicity of oils on insects. These results suggest that oil could be used as potential fumigant and repellenct as a safe pesticide for some of stored-product insects.
\end{abstract}

\section{INTRODUCTION}

Management of stored grain pests is severely dependent upon using of synthetic insecticides. However, application of these synthetic commercial insecticides has led to several serious problems such as environmental deterioration due to chemical residues, insect resistance against these repeatedly used chemicals, deterioration of food grains due to residues and harmfulness of synthetic chemicals to the non-target organisms in the surroundings (Zapata et al., 2010; Perez et al., 2010; Grünwald et al., 2014). Serious health impacts on humans and ecological changes has forced the researchers to find the new ways of stored grains insect pests management and diverting their attention towards the natural products use as insecticides such as the use of plant extracts as repellents (Rajendran \& Sriranjini, 2008). Production of these repellents from plants is less expensive and easy as compared to synthetic chemicals (Shadia, 2011). These chemicals are safe to use for human beings and have minimum effects on the ecosystem. Manyplant extracts are used in different forms such as essential oils and they are proved tobe used as stored products repellents and fumigants that are economically important (Stancicet al., 2011; Khan et al., 2013; Nazeefullahet al., 2014). 


\section{MATERIALS AND METHODS}

\section{1- The insects:}

Adults of Sitophilus oryzae reared on wheat grains and Callosobruchus maculates reared on cowpea seeds in a glass jars (each of approximately $500 \mathrm{ml}$ ) and each jar was covered with muslin cloths and fixed with rubber bands. To have an initial population of insect adults homogenous in age, about 500 adults were introduced into jars containing grains or seeds for egg laying and then kept in an incubator at $28 \pm 2^{\circ} \mathrm{C}$ and $65 \pm 5 \%$ R.H. After three days, all insects were removed from the media and the jars were kept again at controlled conditions. Adults of (1-2 weeks old) S. oryzae and (0-24 hrs old) C. maculates were used for the experiments.

\section{2- Tested oils:}

Oils obtained from El Captain Company for extracting natural oils, plants and cosmetics,

Egypt. Six oils namely; Chili pepper (Capsicum annuum), Garlic (Allium sativum), Tea tree (Melaleuca alternifolia), Peppermint (Mentha pulegium), Cardamom (Elettaria cardamomum) and camphor (Eucalyptus globulus) are tested in the experiments.

\section{3- Fumigant test:}

The fumigant effect of tested oils was determined according to the method described by Prates et al., (1998): 10 insect adults were put into separate $80 \mathrm{ml}$ glass jars. Tested oils at concentrations of $(0.4,0.6$, and $0.8 \mathrm{ml})$ were applied to $5 \mathrm{~cm}$ diameter filter paper. The filter papers were attached to the underside surface of the screw caps of the glass jars. The jars were first covered with nylon mesh. The caps were then attached. This measure was taken in order to prevent a direct contact between insects and the bio-insecticides. Another group of filter papers used for the control group. Mortality percentage was recorded after 5 and 3 days later for S.oryzae and $C$. maculatus, respectively. Means were tested for significance by the one way analysis of variance (ANOVA). When the ANOVA statistics were significant $(P<0.05)$, means were compared using Duncan's multiple range test (Duncan, 1951). Percent of insect mortality was calculated using the corrected Abbot's formula (Abbot, 1925)

\section{4- Repellent effect:}

Repellency of the oils was checked by using the area preference method (Mohan and Fields, 2002) in which filter paper was cut into two equal halves. Different concentrations were made on the one half. The treated paper was allowed to dry for 60 minutes. After drying, the treated paper was stapled together and was adjusted in the Petri dishes. Ten adult beetles were released in the center of both halves. 
Repellency data was taken after a period of 6, 12, 24 and 48 hours. Diet will be provided on both sides (treated and untreated end of filter paper) to decrease mortality due to starvation. Percentage repellency was calculated by counting the insects in untreated half.

\section{RESULTS AND DISCUSSION}

\section{1-Fumigant of oils:}

The toxicity of 6 essential oils; Garlic oil, Chili pepper oil, Cardamom oil, Peppermint oil, eucalyptus oil and Tea tree oil on two stored grains insects, Sitophilus oryzae and Callosobruchus maculates are showed in Table (1). The data represented that Callosobruchus maculates adults were more sensitive than Sitophilus oryzae adults for all tested oils except Garlic oil. On the other hand the peppermint and Tea tree oils were more toxic to S.oryzae while the Chili pepper and the peppermint oils were more toxic for $C$. maculatus. Otherwise, the mortality \% increased as the concentration increased, the highest recorded mortalities were found to be $75.8 \%$ for S. oryzae with peppermint oil and $96.2 \%$ for $C$. maculatus with Chili pepper oil while the lowest mortality were $51.7 \%$ forS.oryzae on Cardamom oil and $48.1 \%$ for $C$. maculatus on Garlic oil at the same concentration (0.8). Our results go with harmony of finding of Mahfuz and Khalequzzaman (2007), tested the fumigant toxicity of they tested five essential oils (EOs), viz. cardamom, cinnamon, clove, eucalyptus and neem oils were investigated against the cowpea weevil, Callosobruchus maculatus. Results revealed that, eucalyptus oil shows the last position for $24 \mathrm{~h}$ and fourth position for 48 $\mathrm{h}$ after treatments. The efficacy in respect of the toxicity followed in the order: clove $>$ cinnamon $>$ cardamom $>$ neem $>$ eucalyptus after $24 \mathrm{~h}$ after treatment, and clove $>$ cinnamon $>$ cardamom $>$ eucalyptus $>$ neem after $48 \mathrm{~h}$ after treatments. Ahmed (2010) tested Essential oils of Tea tree, Cinnamon, Cloves, lemongrass, Thyme, Eucalyptus and Jojoba for their fumigant activity against Callosobruchus maculates and Sitophilus oryzae, he reported that cinnamon and tea tree gave $90.0 \%$ mortality at 8.0 and $16.0 \mu \mathrm{l} / 50 \mathrm{ml}$ air, respectively, at exposure period of 24 hour for $S$. oryzae . Cinnamon, tea tree and thyme essential oils gave100\% mortality at 8.0, 16.0 and $16.0 \mu \mathrm{l} / 50 \mathrm{ml}$ air, respectively, at exposure period of 24 hour for C. maculatus. Rani (2012) study the fumigant toxicity of essential oils isolated from pine, Eucalyptus and coriander against rice weevil, Sitophilus oryzae, adzuki bean weevil, Callosobruchus chinensis and rice moth Corcyra cephalonica. Coriander and eucalyptus oils at $130 \mu \mathrm{g} / \mathrm{cm} 2$, caused $100 \%$ toxicity to all the species within $24 \mathrm{hrs}$ of treatment, whereas pine oil revealed, $90 \%$ mortality at same concentration after 72 hrs of 
treatment. Jahromi, et al. (2014) who stated the terpenes present in the essential oil were responsible for the toxicological action. Symptoms of neurotoxicity were shown by insects.

Table 1. Effect of six natural oils on mortality (\%) of s.oryzae andC.maculatus adults at $28 \pm 2{ }^{\circ} \mathrm{C}$ and $65 \pm 5 \%$ R.H.

\begin{tabular}{|c|c|c|c|}
\hline Oil name & Conc. (w/v) & S.oryzae after 5 days fumigation & $\begin{array}{c}\text { C.maculatus after } 3 \text { days } \\
\text { fumigation }\end{array}$ \\
\hline \multirow{3}{*}{ Garlic } & 0.4 & $17.2 \pm 5.7^{\mathrm{a}}$ & $11.1 \pm 5.7^{\mathrm{a}}$ \\
\hline & 0.6 & $34.4 \pm 3.3^{a}$ & $40.6 \pm 14.4^{b}$ \\
\hline & 0.8 & $65.5 \pm 8.7^{b}$ & $48.1 \pm 8.7^{b}$ \\
\hline \multicolumn{2}{|c|}{ LSD 0.05} & 2.2 & 3.6 \\
\hline \multirow{3}{*}{ Chili Pepper } & 0.4 & $24 \pm 3.3^{a}$ & $74 \pm 8.7 \mathrm{a}$ \\
\hline & 0.6 & $44.7 \pm 8.7^{b}$ & $85.1 \pm 6.6 \mathrm{a}$ \\
\hline & 0.8 & $62 \pm 3.3^{\mathrm{b}}$ & $96.2 \pm 3.3 \mathrm{a}$ \\
\hline \multicolumn{2}{|c|}{ LSD 0.05} & 2 & 2.3 \\
\hline \multirow{3}{*}{ Cardamom } & 0.4 & $13.7 \pm 6.6^{a}$ & $22.2 \pm 10 \mathrm{a}$ \\
\hline & 0.6 & $38 \pm 5.7^{\mathrm{ab}}$ & $40.6 \pm 12 \mathrm{a}$ \\
\hline & 0.8 & $51.7 \pm 8.7^{b}$ & $51.7 \pm 8.7 \mathrm{a}$ \\
\hline \multicolumn{2}{|c|}{ LSD 0.05} & 2.5 & 3.6 \\
\hline \multirow{3}{*}{ Peppermint } & 0.4 & $20.7 \pm 6.6^{\mathrm{a}}$ & $62.9 \pm 8.7 \mathrm{a}$ \\
\hline & 0.6 & $41.3 \pm 8.7^{a}$ & $66.7 \pm 5.8 \mathrm{a}$ \\
\hline & 0.8 & $75.8 \pm 8.7^{b}$ & $85.1 \pm 6.6 \mathrm{a}$ \\
\hline \multicolumn{2}{|c|}{ LSD 0.05} & 2.8 & 2.5 \\
\hline \multirow{3}{*}{ Camphor } & 0.4 & $24 \pm 6.6^{a}$ & $66.7 \pm 10 \mathrm{a}$ \\
\hline & 0.6 & $38 \pm 5.7^{a b}$ & $70.3 \pm 3.3 \mathrm{a}$ \\
\hline & 0.8 & $55.1 \pm 8.7^{b}$ & $77.7 \pm 5.7 \mathrm{a}$ \\
\hline \multicolumn{2}{|c|}{ LSD 0.05} & 2.5 & 2.4 \\
\hline \multirow{3}{*}{ Tea tree } & 0.4 & $44.7 \pm 12^{a}$ & $37 \pm 3.3 \mathrm{a}$ \\
\hline & 0.6 & $62.3 \pm 8.7^{\mathrm{a}}$ & $59.2 \pm 12 a b$ \\
\hline & 0.8 & $72.3 \pm 8.7^{a}$ & $85.1 \pm 8.7 b$ \\
\hline \multicolumn{2}{|c|}{ LSD 0.05} & 3.4 & 3 \\
\hline
\end{tabular}

\section{2-Repellent effect of oils:}

The repellency effect of 6 tested oils againstS.orzyae and C.maculatusadults are represented in Tables (2\&3).

The data showed that S.orzyzae adults more repellence than C.maculatus adults by the 6 tested essential oils and at the first 6 hours of test, as concentration increased repellent effect increased for two insects but the remaining times for S.orzyzae adults, as increased time the repellent effect decreased but for C.maculatus adults, concentration and time were Camphor and Cardamom oils were more effective for repellence of S.orzyae adults while The Chili Pepper and Tea tree oils were more effective for repellence of C.maculatus adults with all its concentrations and times. Our results agree with findings of Sagheer et al. (2011and 2013) who 
finding that serial concentrations were made and maximum percent repellency was shown at highest concentrations also supports that the potential of the plant extracts to cause repellency increases with concentration. But, the results are different for the time factor because in their experiment there is no significant effect of time. It may be contributed towards the method used for experiments. Ibrahim (2011) investigated chemical composition of botanical oil garlic and chamomile its toxic and repellent activity were investigated against three stored product insects, Callosobruchus maculatus (Fab.), Trogoderma granarium (Khapra beetle), and Tribolium castaneum (Herbst). The repellent action of the tested essential oils (garlic, chamomile and neem) was increased with the increasing of concentration with the tested insect species. Fouad (2013) study the repellent activity of essential oils of camphor, castor, cinnamon, clove and mustard against faba bean beetle, Bruchidius incarnates. All essential oils with $4 \%$ concentration repelled the $B$. incarnates adult except castor oil.

Table 2.Effect of six natural oils on repellency (\%) of s.oryzae adults at $28 \pm 2^{\circ} \mathrm{C}$ and $65 \pm 5 \%$ R.H.

\begin{tabular}{|c|c|c|c|c|c|}
\hline \multirow{2}{*}{ Oil name } & \multirow{2}{*}{$\begin{array}{l}\text { Conc. } \\
(w / v) \%\end{array}$} & \multicolumn{4}{|c|}{$\%$ repellency after indicated period hours } \\
\hline & & $6 \mathrm{hrs}$ & $12 \mathrm{hrs}$ & $24 \mathrm{hrs}$ & 28hrs \\
\hline \multirow{4}{*}{ Garlic } & 0.04 & 90 & 76.6 & 53.3 & 33.3 \\
\hline & 0.06 & 96.6 & 86.6 & 60 & 53.3 \\
\hline & 0.08 & 100 & 100 & 70 & 66.6 \\
\hline & 0.1 & 100 & 100 & 73.3 & 66.6 \\
\hline \multirow{4}{*}{ chili Pepper } & 0.04 & 100 & 86.6 & 73.3 & 43.3 \\
\hline & 0.06 & 100 & 100 & 80 & 56.6 \\
\hline & 0.08 & 100 & 100 & 96.6 & 73.3 \\
\hline & 0.1 & 100 & 100 & 96.6 & 80 \\
\hline \multirow{4}{*}{ Cardamom } & 0.04 & 100 & 100 & 96.6 & 93.3 \\
\hline & 0.06 & 100 & 100 & 100 & 96.6 \\
\hline & 0.08 & 100 & 100 & 100 & 100 \\
\hline & 0.1 & 100 & 100 & 100 & 100 \\
\hline \multirow{4}{*}{ Peppermint } & 0.04 & 100 & 100 & 50 & 13.3 \\
\hline & 0.06 & 100 & 100 & 63.3 & 26.6 \\
\hline & 0.08 & 100 & 100 & 73.3 & 46.6 \\
\hline & 0.1 & 100 & 100 & 73.3 & 63.3 \\
\hline \multirow{4}{*}{ Camphor } & 0.04 & 100 & 100 & 90 & 73.3 \\
\hline & 0.06 & 100 & 100 & 96.6 & 76.6 \\
\hline & 0.08 & 100 & 100 & 100 & 100 \\
\hline & 0.1 & 100 & 100 & 100 & 100 \\
\hline \multirow{4}{*}{ Tea tree } & 0.04 & 66.6 & 56.6 & 40 & 26.6 \\
\hline & 0.06 & 83.3 & 76.6 & 53.3 & 40 \\
\hline & 0.08 & 90 & 83.3 & 56.6 & 50 \\
\hline & 0.1 & 100 & 100 & 93.3 & 86.6 \\
\hline
\end{tabular}


Table 3.Effect of six natural oils on mortality (\%) of C.maculatus adults at $28 \pm 2{ }^{\circ} \mathrm{C}$ and $65 \pm 5 \%$ R.H.

\begin{tabular}{|c|c|c|c|c|c|}
\hline \multirow{2}{*}{ Oil name } & \multirow{2}{*}{$\begin{array}{l}\text { Conc. } \\
(w / v) \%\end{array}$} & \multicolumn{4}{|c|}{$\%$ repellency after indicated period hours } \\
\hline & & $6 \mathrm{hrs}$ & $12 \mathrm{hrs}$ & $24 \mathrm{hrs}$ & 28hrs \\
\hline \multirow{4}{*}{ Garlic } & 0.04 & 33.3 & 53.3 & 50 & 70 \\
\hline & 0.06 & 70 & 70 & 70 & 70 \\
\hline & 0.08 & 70 & 66.6 & 43.3 & 56.6 \\
\hline & 0.1 & 70 & 50 & 60 & 60 \\
\hline \multirow{4}{*}{ chili Pepper } & 0.04 & 90 & 100 & 100 & 100 \\
\hline & 0.06 & 100 & 100 & 100 & 100 \\
\hline & 0.08 & 100 & 100 & 90 & 80 \\
\hline & 0.1 & 100 & 100 & 100 & 100 \\
\hline \multirow{4}{*}{ Cardamom } & 0.04 & 73.3 & 60 & 70 & 80 \\
\hline & 0.06 & 76.6 & 50 & 50 & 60 \\
\hline & 0.08 & 80 & 50 & 50 & 40 \\
\hline & 0.1 & 80 & 60 & 56.6 & 50 \\
\hline \multirow{4}{*}{ Peppermint } & 0.04 & 50 & 70 & 60 & 60 \\
\hline & 0.06 & 60 & 50 & 50 & 30 \\
\hline & 0.08 & 63.3 & 66.6 & 63.3 & 60 \\
\hline & 0.1 & 90 & 83.3 & 70 & 70 \\
\hline \multirow{4}{*}{ Camphor } & 0.04 & 70 & 73.3 & 66.6 & 70 \\
\hline & 0.06 & 70 & 50 & 40 & 70 \\
\hline & 0.08 & 80 & 80 & 50 & 60 \\
\hline & 0.1 & 80 & 80 & 60 & 76.6 \\
\hline \multirow{4}{*}{ Tea tree } & 0.04 & 90 & 90 & 86.6 & 90 \\
\hline & 0.06 & 90 & 90 & 73.3 & 90 \\
\hline & 0.08 & 93.3 & 93.3 & 83.3 & 96.6 \\
\hline & 0.1 & 100 & 100 & 80 & 80 \\
\hline
\end{tabular}




\section{REFERENCES}

1. Abbot, W. J. 1925. A method for computing the effectiveness of an insecticide.J. Econ. Entomol., 18: 265-27.

2. Ahmed, M. E. 2010. Fumigant toxicity of seven essential oils against the cowpea weevil, Callosobruchus maculatus (F.) and the rice weevil, Sitophilus oryzae (L.). Egypt. Acad. J. biolog. Sci., 2 (1): 1- 6.

3. Duncan, D. B. 1951. A significance test for differences between ranked treatments in an analysis of variance. Virginia J. Sci., I. 2:171-189.

4. Fouad, H. A. 2013. Bioactivity of Five Essential Oils Against Bruchidius incarnatus (Bohemann, 1833). Not Sci Biol, 5(3):354-359.

5. Grünwald S; A. Fast; K. Mülle; M. Boll; A. Kler and B. Bonnländer. 2014. Feeding agrape seed extract extends the survival of the red flour beetle Tribolium castaneum under heat-stress depending on nrf- 2 , jnk- 1 , and foxo- 1 homologous genes but independent of catechinmonomers. Nutrition and Medicine; 2(1):415422.

6. Ibrahim, Sahar I. A. 2011. Repellent and insecticidal activity of derived plant oils against some stored grain insects. J. Plant Prot. Path., Mansoura Univ., Vol. 2 (10): 893 - 903, 2011

7. Jahromi M. G; A. A. Pourmirza and M. H. Safaralizadeh. 2014. Repellent effect of sirinol (garlic emulsion) against Lasioderma serricorne (Coleoptera: Anobiidae) and Tribolium castaneum (Coleoptera: Tenebrionidae) by three laboratory methods. Afric. J. Biotechn; 11(2):280-288.

8. Khan F. Z. A; M. Sagheer; M. Hasan; S. Saeed; K. Ali and H. T. Gul. 2013.Toxicological and repellent potential of some plant extracts against stored product insect pest, Tribolium castaneum (Herbst.) (Coleoptera: Tenebrionidae). Intern. J. Biosci; 3(9):280-286.

9. Mahfuz and M. Khalequzzaman. 2007. Contact and fumigant toxicity of essential Oils against Callosobruchus maculatus. Univ. J. zool. Rajshahi Univ. Vol. 26: 6366.

10. Mohan, S. and P. G. Fields. 2002. A simple technique to assess compounds that are repellent or attractive to stored product insects. J. St. Prod. Res; 38, 23-31.

11. Nazeefullah, S; G. Dastagir and B. Ahmad. 2014. Effect of cold water extracts of Acacia modesta Wall. and Glycyrrhiza glabra Linn. on Tribolium castaneum and Lemna minor. Pakistan J. Pharma. Sci.; 27(2):217-222. 
12. Perez S. G; M. A. R Lopez; M. A. Z. Sanchez and N. C. C. Ortega. 2010. Activity of essential oils as a bio-rational alternative to control coleopteran insects in stored grains. J. Medic. Plant Res; 4:2827-2835.

13. Prates, H. T; J. P. Santos; J. M. Waquil; J. D. Fabris; A. B. Oliveira and J. E. Forster. 1998. Insecticidal activity of monoterpenes against Rhyzopertha dominica (F.) and T. castaneum (Herbst). J. St. Prod. Res; 34, 243-249.

14. Rajendran, S and V. Sriranjini. 2008. Plant products as fumigants for stored product insect control. J. St. Prod. Res; 44:126-135.

15. Rani, P. U. (2012): Fumigant and contact toxic potential of essential oils from plant extracts against stored product pests. J. Biopest; 5(2): 120-128.

16. Rogers, S. O. and A. J. Bendich. 1985. Extraction of DNA from milligram amounts of fresh herbarium and mummified plant tissues. Plant Mol. Boil; 5: 69-76.

17. Sagheer M; M. Hasan; M. A. Latif and J. Iqbal. 2011. Evaluation of some Indigenous medicinal plants as a source of toxicant, repellent and growth inhibitors against Tribolium castaneum (Coleoptera: Tenebrionidae). Pakistan Entomologist; 33:87-91.

18. Sagheer M; M. Hasan; H. Rehman; F. Z. A. Khan; H. T. Gul and S. R. Haidri. 2013. Growth Regulatory Potential of Five Indigenous Plant Extracts against Tribolium castaneum (Herbst) (Coleoptera: Tenebrionidae). Intern. J. Biosci; 3(12):50-54.

19. Shadia E. A. E. A. 2011. Control Strategies of Stored Product Pests. J. Entomol; 8:101-122.

20. Stancic, M. R; D; D. Coprean; D. Sava; S. Dobrinas; L. Miron and S. Schiopu. 2011. Use of Garlic, Absinthium and Celandine extract as natural repellents. Environ. Eng. and Manag. J; 10:445-449.

21. Thappa H. S. and M. P. Menon. 1973. Effect of ionizing radiations on Lycopersico mesculentum. Mill. Madras Agric. J; 60 (9): 1622-1628 (c.f. PL. Br. Abst., 45(7): 5897, 1975).

22. Zapata N. and G. Smagghe. 2010. Repellency and toxicity of essential oils from the leaves and bark of Laurelia sempervirens and Drimys winteri against Tribolium castaneum. Industrial Crops and products. 


\section{التبخير و التأثير الطارد لبعض الزيوت الطبيعية ضد حشرتي سوسة الارز وخنفساء اللوبيا من النوع}

\section{Callosobruchus maculatus}

$$
\begin{aligned}
& \text { نيللى أحمد حسن عبد الفتاح } \\
& \text { معهُ بحوث وقاية النباتات - مركز البحوث الزراعية - الدقى - الجيزة - مصر }
\end{aligned}
$$

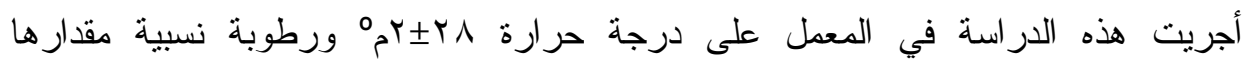

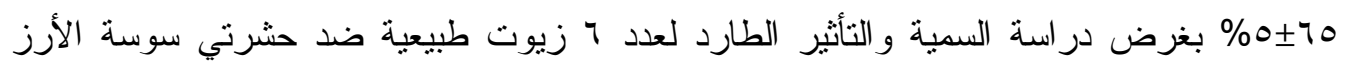
وخنفساء اللوبيا حيث تم عمل ثلاثة تركيز ات من كل زيت من هذه الزيوت لدر اسة تاثير التبخير علي لئي السمية وعمل أربع تركيزات من كل زيت أيضا لدر اسة نسبة الطرد لهاتين الحشرثين.

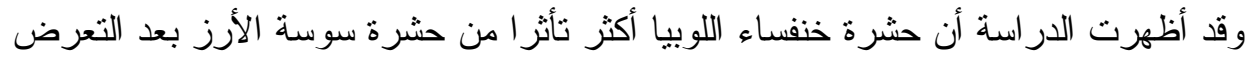

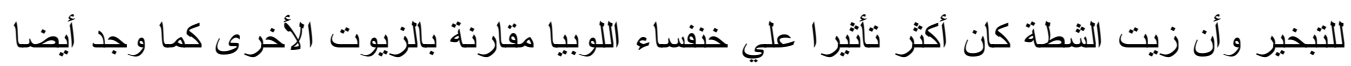
أن التأثثر الطارد لهذه الزيوت كان كبير ا بالنسبة لسوسة الأرز مقارنة بخنفساء اللوبيا، أن زيت

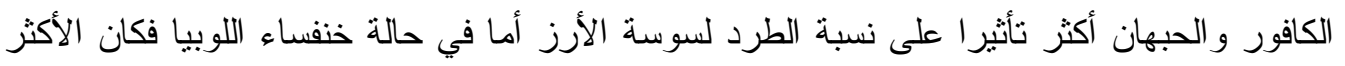

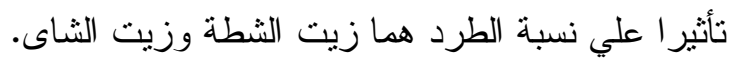

